\title{
Antibiotic resistance profile of gram-negative bacteria isolated from dog nasal swab samples, and antibacterial and antioxidant activities of aqueous extracts of Alpinia purpurta (Vieill.) K. Schum (Zingiberaceae)
}

\section{Perfil de resistência a antibióticos de bactérias gram- negativas isoladas de amostras de swab nasal de cães e atividades antibacteriana e antioxidante de extratos aquosos de Alpinia purpurta (Vieill.) K. Schum. (Zingiberaceae)}

Camila de Cuffa Matusaiki ${ }^{1 *}$; Rafaela Galves Ferreira ${ }^{1}$; Luciana Kazue Otutumi2; Isabela Carvalho dos Santos ${ }^{3}$; Felipe André Pereira Ramos ${ }^{4}$; Taniara Suelen Mezalira3; Ezilda Jacomassi5; Lidiane Nunes Barbosa²; Daniela Dib Gonçalves' ${ }^{6}$; Andréia Assunção Soares ${ }^{6}$

Highlights

An extract of $A$. purpurata rhizomes showed higher antioxidant capacity than $A$. purpurata leaf extract. A high rate of resistance to $\beta$-lactams was found for gram-negative bacteria isolated from nasal swabs of dogs.

Aqueous leaf extracts have high levels of total phenolic compounds.

1 Discentes do Curso de Graduação em Medicina Veterinária, bolsista PEBIC/CNPq, Universidade Paranaense, UNIPAR, Umuarama, PR, Brasil. E-mail: camila_cuffa@hotmail.com; rafaelagalvesferreira@gmail.com

2 Profa Dra , Programa de Pós-Graduação em Ciência Animal com Ênfase em Produtos Bioativos, UNIPAR, Umuarama, PR, Brasil. E-mail: Ikotutumi@gmail.com; linuba2@gmail.com

3 Discentes do Curso de Doutorado do Programa de Pós-Graduação em Ciência Animal com Ênfase em Produtos Bioativos, UNIPAR, Umuarama, PR, Brasil. E-mail: isacarsan@gmail.com; tani_mezalira@hotmail.com

${ }^{4}$ Discente do Curso de Mestrado Profissional em Plantas Medicinais e Fitoterápicos na Atenção Básica, UNIPAR, Umuarama, Brasil. E-mail: felipe.ramos@edu.unipar.br

${ }^{5}$ Prof $^{a}$ Dra $^{a}$, Curso de Mestrado Profissional em Plantas Medicinais e Fitoterápicos na Atenção Básica, UNIPAR, Umuarama, Brasil. E-mail: ezilda@prof.unipar.br

${ }^{6}$ Profa $^{a}$ Dra, Curso de Mestrado Profissional em Plantas Medicinais e Fitoterápicos na Atenção Básica e do Programa de Pós-Graduação em Ciência Animal com Ênfase em Produtos Bioativos, UNIPAR, Umuarama, PR, Brasil. E-mail: danieladib@prof.unipar.br; andreia.assuncao@prof.unipar.br

* Author for correspondence

Received: Mar. 22, 2020 - Approved: July 02, 2020 


\section{Abstract}

The indiscriminate use of antibiotics in veterinary medicine and their negligent use among dog owners have contributed to the rise of antibiotic resistance in microorganisms found in pets. In addition, the search for medicinal plants with antibacterial properties has made the evaluation of aqueous extracts of Alpinia purpurata (Vieill.) K. Schum an important issue. Thus, the aim of this work was to determine the antibiotic resistance profile of gram-negative bacteria isolated from nasal swab samples of dogs and assess the antibacterial activity of the aqueous extracts of leaves and rhizomes of $A$. purpurata. The bacteria identified were tested using the agar disc diffusion assay for the evaluation of antibiotic resistance. A total of 16 isolates were obtained from the 19 samples collected, with a high prevalence of Escherichia coli $(n=5)$. There was a high rate of resistance to $\beta$-lactams, where the highest percentage was seen for amoxicillin (72.5\%). Aqueous leaf extracts had high levels of total phenolic compounds $\left(637.47 \mu \mathrm{g} \mathrm{GAE} \mathrm{mg}{ }^{-1}\right)$, differing significantly $(p<$ 0.05) from aqueous rhizome extracts $\left(228.64 \mu \mathrm{g} \mathrm{GAE} \mathrm{mg}^{-1}\right)$. There was no significant difference in EC50 of DPPH values between the aqueous extracts; however, the antioxidant capacity of rhizome extracts had higher values than leaf extracts. The minimum inhibitory concentration (MIC) of leaves and rhizomes for the evaluated bacteria ranged from 9000 to $32,000 \mu \mathrm{g} \mathrm{mL}^{-1}$. For the minimum bactericidal concentration (MBC), most bacteria showed an MBC over $38,400 \mu \mathrm{g} \mathrm{mL}^{-1}$ for the rhizome. In conclusion, the bacteria isolated from dog nasal swabs showed a high resistance profile for the antibiotics of the penicillin class. Additionally, the results from the analysis of the aqueous extracts of rhizomes and leaves of $A$. purpurata showed an antimicrobial effect possibly associated with a high content of total phenolic compounds; these results can create a scope for using these extracts together with conventional antibiotics to control the emergence of antibiotic resistance among microbial species.

Key words: Antimicrobial. Escherichia coli. Ginger. Serratia liquefaciens. Hafnia alvei. Pantoea agglomerans.

\section{Resumo}

O uso indiscriminado de antibióticos na Medicina Veterinária e negligência de tutores de cães no uso adequado contribuíram no aumento de resistência em animais de companhia. Além disso, a busca por plantas medicinais que tenham efeito antibacteriano tornou importante a avaliação de extratos aquosos de Alpinia purpurata (Vieill.) K. Schum. Dessa forma, o objetivo do trabalho foi determinar o perfil de resistência aos antibióticos de bactérias Gram-negativas isoladas de amostras de swabs nasais de cães e verificar a atividade antibacteriana dos extratos aquosos das folhas e dos rizomas de $A$. purpurata. As bactérias identificadas foram submetidas à técnica de disco difusão em ágar para avaliação da resistência aos antibióticos. Das 19 amostras colhidas, foram isoladas 16 bactérias, com maior prevalência para Escherichia coli $(n=5)$. Verificou-se um alto índice de resistência aos $\beta$-lactâmicos testados, com maior percentual para amoxicilina (72,5\%). Os extratos aquosos das folhas apresentam elevados teores de compostos fenólicos totais $\left(637,47 \mu \mathrm{g} \mathrm{GAE} \mathrm{mg}{ }^{-1}\right.$ extrato), sendo diferente $(p<0,05)$ dos extratos aquosos dos rizomas $(228,64 \mu \mathrm{g}$ GAE mg-1 extrato). Não houve diferença significativa nos valores de $\mathrm{EC}_{50 \text { - }}$ DPPH para os extratos aquosos, entretanto, para a capacidade antioxidante FRAP, os extratos dos rizomas de $A$. purpurata demonstraram maiores valores quando comparados com os extratos aquosos das folhas. A Concentração Inibitória Mínima (CIM) das folhas e rizomas para as bactérias avaliadas variaram entre 9.000 a $32.000 \mu \mathrm{g} \mathrm{mL}^{-1}$. Para a Concentração Bactericida Mínima (CBM), a maioria das bactérias apresentaram CBM acima de $38.400 \mu \mathrm{g}$ 
$\mathrm{mL}^{-1}$ para o rizoma. Conclui-se que as bactérias isoladas de swab nasal de cães apresentam alto perfil de resistência aos antibióticos da classe das penicilinas, no entanto, os resultados dos extratos aquosos dos rizomas e das folhas de $A$. purpurata sinalizam efeito antimicrobiano possivelmente associado ao elevado teor de compostos fenólicos totais, podendo ser utilizado em conjunto aos antibióticos convencionais, reduzindo assim sua resistência.

Palavras-chave: Antimicrobianos. Escherichia coli. Gengibre. Serratia liquefaciens. Hafnia alvei. Pantoea agglomerans.

\section{Introduction}

Antibiotics are drugs that have revolutionized the treatment of infectious diseases caused by bacteria and have tremendously reduced morbidity and mortality rates associated with bacterial infections worldwide (Costa \& Silva, 2017). However, their indiscriminate use has led to the emergence of antibiotic resistance (Kadwalia et al., 2019; Macedo, 2019), reducing the options of effective drugs for the treatment of several infections, thus increasing the risk of clinical complications in patients (Costa \& Silva, 2017).

Studies have reported the transmission of several multiresistant bacteria between humans and animals (Drougka et al., 2016; Leite-Martins et al., 2015; Wendlandt et al., 2015), and dogs and cats represent a potential source for the spread of antibiotic resistance, due to the wide use of these agents in veterinary routine and the close contact between them and humans (Leite-Martins et al., 2014; Wieler, Ewers, Guenther, Walther, \& Lubke-Becker, 2011).

Bacterial resistance occurs when a bacterium acquires or alters its genes, thus managing to interfere with the mechanism of action of the antibiotic. It may occur by the spontaneous mutation of DNA or by transformation and transfer of plasmids (Bozdogan et al., 1999).
There are many examples of increased antimicrobial resistance among microorganisms found in various animal species. This is worrisome because many of these microorganisms have become resistant to antimicrobials used in human medicine (Bahr Arias \& Carrilho, 2012), and because bacteria serve as reservoirs of resistant genes and could transfer this resistance to human-adapted pathogens or to the human gut microbiota via direct contact, food or the environment (Argudín et al., 2017).

Natural antimicrobials found in medicinal plants can act against infections caused by microorganisms. In recent years, several medicinal plants and spices have attracted research interest due to their medicinal potential (Manandhar, Luitel, \& Dahal, 2019). Bioactive compounds isolated from various parts of plant species are showing a boost in new scientific research in the fields of biochemistry, pharmacology, and medicine for the development of new alternative therapeutic agents (Ghosh \& Rangan, 2013).

Plants of the family Zingiberaceae have garnered special attention because of their ability to produce many bioactive compounds used in the pharmaceutical and cosmetic industries as antioxidants and antimicrobials (Chan \& Wong, 2015). 
Among the species of this family, the medicinal potential of Alpinia purpurata (Vieill.) K. Schum, popularly known as red ginger (used as an ornament), has been investigated. Different parts of this plant produce bioactive compounds (phenolic compounds) with therapeutic properties (Chan \& Wong, 2015; Sumabranian \& Suja, 2011) and they have been recognized as safe by the American Food and Drug administration (FDA) (Azizi et al., 2015).

Al-Enazi (2018) evaluated the acute toxicity $\left(L D_{50}\right)$ of the aqueous extract of $A$. purpurata and demonstrated that up to 5000 $\mathrm{mg} \mathrm{kg}^{-1}$ did not produce any symptoms of acute toxicity in rats. Thus, this species can be used in the treatment of infections.

Different extracts of red ginger leaves, rhizomes, and roots have demonstrated antioxidant and antimicrobial activities associated with their bioactive compounds (Ghosh \& Rangan, 2013; Kona, Thofeeq, \& Venkata, 2015; Sahoo, Singhi, \& Nayak, 2014; Soares et al., 2018; Villaflores et al., 2011).

Thus, the aim of this work was to evaluate the antimicrobial resistance profile of gram-negative bacteria found in dog nasal swabs, and to determine the antibacterial and antioxidant activities of the aqueous extracts of the leaves and rhizomes of $A$. purpurata obtained from the Medicinal Garden of the Paranaense University, Umuarama-PR.

\section{Materials and Methods}

This project was approved by the Research Ethics Committee Involving Animal Experimentation (Comitê de Ética em Pesquisa Envolvendo Experimentação Animal [CEPEEA]) of the Paranaense University under protocol $32876 / 2018$.
Nineteen nasal swab samples were obtained from dogs belonging to students of the veterinary medicine course of the Paranaense University, UNIPAR. To determine the number of samples, the total number of veterinary medicine students enrolled $(\mathrm{N}=$ 181 ) in the year of 2017 was taken into account, which was $10 \%$ of the students.

Isolation and identification of gram-negative bacterial strains

The 19 nasal swabs were collected according to the following procedure: the swab was first moistened with Stuart's transport medium and then introduced into the animal's nasal orifice, pushing it with rotating movements, and the swab was then removed and stored in the transport medium and sent to the Laboratory of Preventive Veterinary Medicine and Public Health of the PostGraduate Program in Animal Science of the Paranaense University.

Tubes containing $3.0 \mathrm{~mL}$ of brain heart infusion (BHI) medium were inoculated with swabs and kept in a microbiological incubator for $24 \mathrm{~h} 37^{\circ} \mathrm{C}$. The cultures obtained streaked on MacConkey agar and incubated at $37^{\circ} \mathrm{C}$ for $24 \mathrm{~h}$ for isolation of single colonies. The colonies with higher prevalence were isolated and then submitted to macroscopic observation (colony characteristics) and microscopic characteristics according to the methodology described by Quinn, Carter, Markey and Carter (1994).

The biochemical identification of bacteria belonging to the order Enterobacteriales was made using the following tests: sulfide indol motility - SIM, triple sugar iron agar - TSI, lysine iron agar - 
LIA, Simmons citrate agar and urea broth. For storage, all the selected single colonies were grown in $\mathrm{BHI}$ medium and then stored in $80 \%$ glycerol at $-20^{\circ} \mathrm{C}$.

\section{Phenotypic antibiotic sensitivity tests}

The agar disc diffusion assay was used according to the recommendations of the Clinical and Laboratory Standards Institute [CLSI] (2018).

Twelve antibiotics of the following classes were tested: $\beta$-lactams: ampicillin $(10 \mu \mathrm{g})$, amoxicillin $(10 \mu \mathrm{g})$ and amoxicillin + clavulanate $(20 / 10 \mu \mathrm{g})$; cefoxitin $(30 \mu \mathrm{g})$, ceftriaxone $(30 \mu \mathrm{g})$, cefotaxime $(30 \mu \mathrm{g})$ and ceftazidime $(30 \mu \mathrm{g})$; aminoglycosides: gentamicin $(10 \mu \mathrm{g})$ and amikacin $(30 \mu \mathrm{g})$; fluorquinolones: ciprofloxacin $(5 \mu \mathrm{g})$ and enrofloxacin (10 $\mu \mathrm{g}) ;$ and sulfonamide: sulfazotrim $(25 \mu \mathrm{g})$.

\section{Botanical material}

Botanical material was collected from Horto Medicinal - UNIPAR campus, Umuarama-PR, (geographical coordinates $23^{\circ} 45^{\prime \prime} 44.9^{\prime \prime} \mathrm{S}$ and $53^{\circ} 16^{\prime \prime} 17.5^{\prime \prime} \mathrm{W}$ ) located in the city of Umuarama, northwestern region of $\mathrm{PR}$, and was deposited in the Horto Medicinal Herbarium of Campus II of UNIPAR, under registration No. 344.

The rhizomes and leaves of $A$. purpurata were collected during April 2017. The leaves and rhizomes were washed under running water, dried with paper towels and immediately dried further in a forced circulation oven at $35^{\circ} \mathrm{C}$ for 20 days (leaves) or $40^{\circ} \mathrm{C}$ for 20 days (rhizomes). The rhizomes were then cut into slices and the leaves left whole. The dried leaves and rhizomes were ground in an industrial blender (bench) until powder was obtained (Otunola, Oloyede, Oladiji, \& Afolayan, 2014).

The powder samples of rhizomes and leaves were subjected to aqueous extraction according to the method described by Otunola et al. (2014) with some modifications. A total of $40 \mathrm{~g}$ of each powder sample was added to $800 \mathrm{~mL}\left(5 \% \mathrm{w} \mathrm{v}^{-1}\right)$ of boiling distilled water (95 $100^{\circ} \mathrm{C}$ ) under stirring for $10 \mathrm{~min}$. The aqueous extract was filtered and freeze-dried for 48 $h$, and the dried extract was stored in airtight glass bottles in the freezer $\left(-20^{\circ} \mathrm{C}\right)$ for further analysis.

\section{Determination of total phenolic compounds}

The concentration of total phenolic compounds in aqueous extracts (leaves and rhizomes) was determined by the FolinCiocalteu method (Singleton \& Rossi, 1965), with gallic acid (GA) used as reference, and the results were expressed in $\mathrm{mg} \mathrm{mL}^{-1}$ of $\mathrm{GA}$ equivalents ( $m g$ GAE $\mathrm{mL}^{-1}$ ).

\section{Antioxidant activity DPPH test}

The sequestrating activity of the free radical 1.1 diphenyl 2 picrylhydrazil (DPPH) was performed according to Pyrzynska and Pekal (2013). The sequestrating activity was expressed as \% of free radical sequestration efficiency, i.e., \% = (1 - Sample/Control) $\times 100$.

The synthetic butylhydroxytoluene antioxidant $\mathrm{BHT}\left(0.2 \mathrm{mg} \mathrm{mL}^{-1}\right)$ was used as the positive control. The results were expressed as EC50 (concentration of extract expressing $50 \%$ antioxidant activity $-\mathrm{mg} \mathrm{mL}^{-1}$ ), which was obtained by interpolation of linear regression analysis. 
Total antioxidant capacity FRAP test

The ferric reducing antioxidant power (FRAP) assay was performed according to Lim \& Lim (2013). The standard used was Trolox ${ }^{\circledR}$ (Sigma) and results were expressed in nmol Trolox equivalents $\mathrm{mg}^{-1}$ extract.

Determination of minimum inhibitory concentration (MIC) and minimum bactericidal concentration (MBC)

The determination of the minimum inhibitory concentration (MIC) was performed in accordance with the microdilution assay (CLSI, 2018).

Different concentrations $(600,1200$, $2400,4800,9600,19,200,38,400$ and 64,000 $\mu \mathrm{g} \mathrm{mL}-1$ ) of aqueous extracts of rhizomes and leaves of $A$. purpurata were prepared following the methods of Kuete (2010) for the determination of MIC. The MIC assays were performed in triplicate. After incubation at 37 ${ }^{\circ} \mathrm{C} 24 \mathrm{~h}, 10 \mu \mathrm{L}$ of $10 \%$ triphenyltetrazolium 2.3.5-chloride (TTC) developer were added, and the microplates were incubated again for $30 \mathrm{~min}$. Samples with any pink tint (occurrence of bacterial growth) were considered positive. MIC was defined as the lowest concentration of the extract, in $\mathrm{g} \mathrm{mL}^{-1}$, capable of preventing bacterial growth (Barbosa et al., 2014; Bona, Pinto, Fruet, Jorge, \& Moura, 2014).

Minimum bactericidal concentration (MBC) was determined using the microdilution broth method in 96-well polystyrene microplates (CLSI, 2013). A sample of the content of each of the 96 wells was streaked on a plate containing Müeller Hinton agar, with the aid of a replicator, and the plates incubated at $36{ }^{\circ} \mathrm{C} \pm 0.5$ for $24 \mathrm{~h}$. MBC was determined by the absence of visible bacterial growth after the incubation period.

\section{Statistical analysis}

Graphs were prepared to express the absolute $(\mathrm{n})$ and relative (\%) frequency of isolated bacteria and resistance to the main antibiotics evaluated. The results of the determination of total phenolic compounds and antioxidant activity (DPPH and FRAP) of rhizome and leaves of $A$. purpurata were expressed as mean \pm standard error. The results of the MIC of rhizome and leaves the bacteria tested were expressed as the mean. The differences (rhizome and leaves) were compared by the Studentt-test for independent samples at a $5 \%$ significance level using the Bioestat 5.0 statistical program (Ayres, Ayres, Ayres, \& Santos, 2007). The results of MBC were expressed as the absolute frequency (n) for each single species for concentrations above 38,400 and below $64,000 \mu \mathrm{g} \mathrm{mL}^{-1}$.

\section{Results and Discussion}

From the 19 nasal swab samples obtained from dogs belonging to veterinary medicine students, 16 isolates showed growth on MacConkey agar. The 16 isolated bacteria were identified as belonging to four species, with a higher prevalence of Escherichia coli $(E$. coli) at $31.25 \%(5 / 16)$ (Figure 1$)$. 


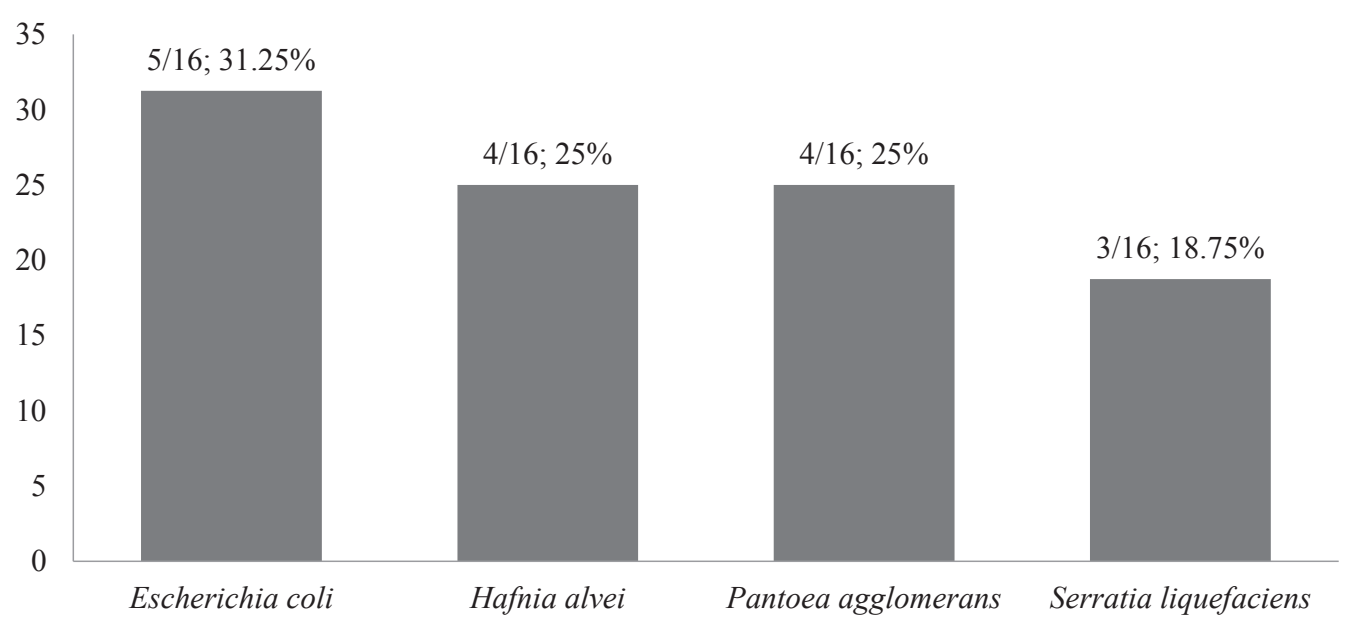

Figure 1. Number and percentage of the 16 enterobacterial isolates from dog nasal swabs taken by students of the veterinary medicine course of the Paranaense University, UNIPAR, 2018.

Among the antibiotics studied, 11/16 $(68.75 \%)$ of the isolates were resistant to amoxicillin, 10/16 (62.5\%) resistant to ampicillin and $10 / 16(62.5 \%)$ resistant to amoxicillin combined with clavulanic acid. The other antibiotics tested showed $100 \%$ sensitivity.
When the level of resistance of enterobacterial isolates was evaluated, it was evident that Serratia liquefaciens was $100 \%$ resistant to the three antibiotics: amoxicillin, ampicillin and amoxicillin + clavulanate (Figure 2).

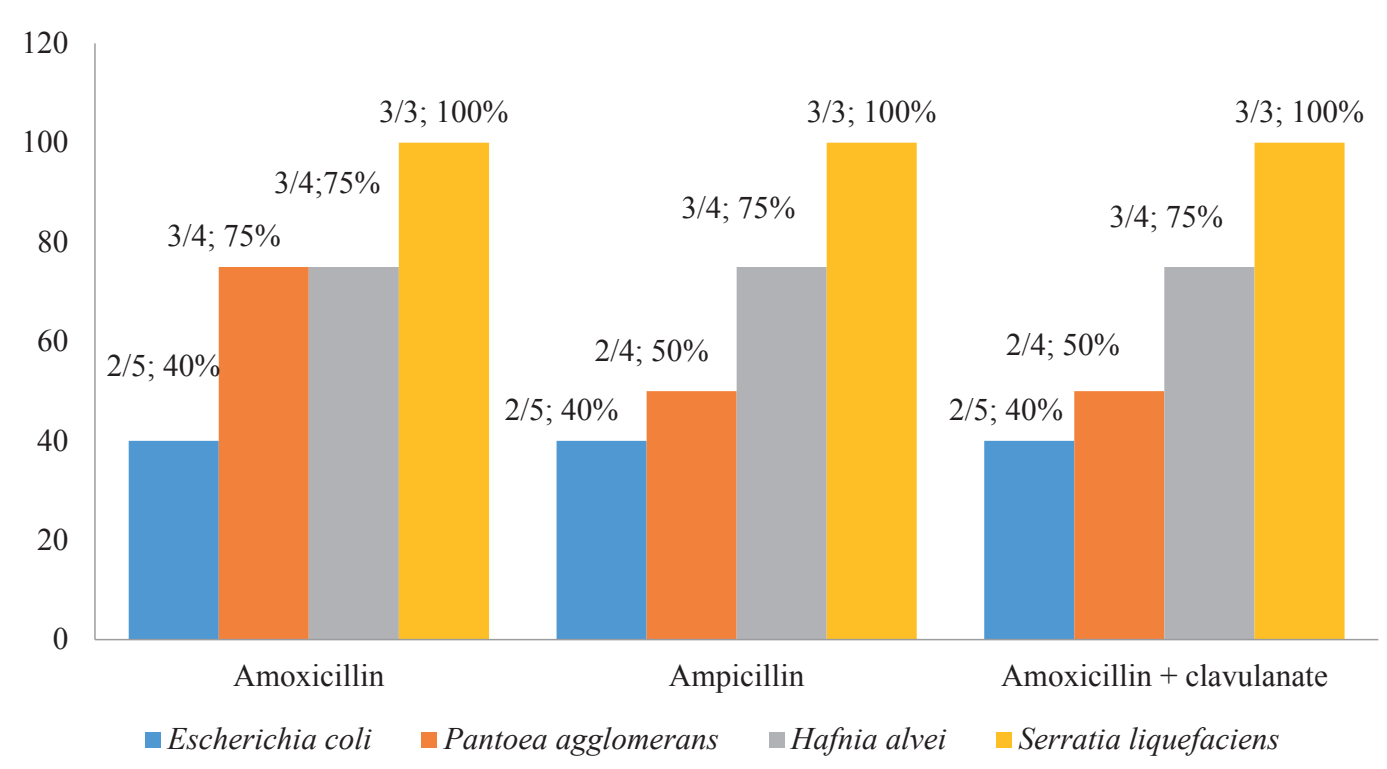

Figure 2. Number and percentage of resistant strains among 16 enterobacterial isolates from dog nasal swab samples taken by students of the veterinary medicine course at the Universidade Paranaense - UNIPAR. 
Among the four bacterial species isolated, three are classified as having intrinsic resistance to antibiotics of the penicillin class. They have the characteristics and genes for resistance to the antibiotics used in research, since according to Del Fio, Matos and Groppo (2000), intrinsic resistance is part of the natural/phenotypic characteristics of the microorganism; i.e., it is part of its genetic inheritance, which is transmitted vertically to the offspring without loss of the characteristic and without any risk to therapeutic treatment (Del Fio et al., 2000). Moreover, it has been reported that there is a high percentage of beta-lactam-resistant Enterobacteriaceae in feces of dogs (Dupouy et al., 2019) and canine rectal swabs (Urumova, 2019).

A study evaluating a community pharmacy in the state of Paraíba (Paula, 2014) and a study by Lima, Gallani, Toledo and Lopes (2008) in a company that used a pharmaceutical benefit management system in the region of
Campinas, SP, showed that amoxicillin was the most prescribed drug. This suggests that the high resistance profile may be associated with its use without criteria.

The concentration of total phenolic compounds in the aqueous extracts of the leaves and rhizomes of $A$. purpurata, determined using the Folin-Ciocalteu reagent, is shown in Table 1. The results showed that the aqueous leaf extracts have high contents of these compounds $(637.47 \pm 6.80 \mu \mathrm{g} \mathrm{GAE}$ $\mathrm{mg}^{-1}$ extract), being statistically different ( $p$ $<0.05$ ) from the aqueous extracts of rhizomes

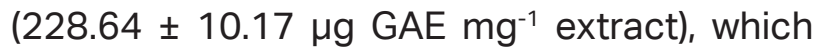
could explain the greater antioxidant activity for the aqueous extract of leaves, since several studies have indicated that antioxidant activity is directly related to the total content of phenolic compounds produced by plants (Cutrim, Teles, Mouchrek, Mouchrek, \& Everton, 2019), which act mainly in the sequestration of free radicals (Sahoo et al., 2014).

\section{Table 1}

Mean \pm standard error of mean of concentrations of total phenolic compounds in aqueous extracts of rhizomes and leaves of $A$. purpurata

A. purpurata

Rhizomes

Leaves
Total phenolic compounds ( $\mu \mathrm{g}$ GAE/mg extract)

$228.64 \pm 10.17^{a}$

$637.47 \pm 6.80^{\mathrm{b}}$

GAE: gallic acid equivalents (Sigma standard). Data expressed as mean \pm SEM $(n=4)$. Means followed by different letters in the column differ according to the t-test for independent samples at the $5 \%$ significance level.

According to Shareef, Muhammed, Hussein and Hammed (2016), plants produce different chemically heterogeneous groups of these phenolic compounds, which, according to their chemical diversity, have various functions.

Regarding the results of the antioxidant activity measured by the DPPH and FRAP methods, there was no significant difference in the EC50 of DPPH values for the aqueous extracts of the rhizomes and leaves of $A$. purpurata (Table 2). However, for the total antioxidant capacity (FRAP), rhizome extracts showed a higher mean $(p<0.05)$ compared to leaf extracts (Table 2). 


\section{Table 2}

EC50-antioxidant activity (DPPH) and total antioxidant capacity (FRAP) of aqueous extracts of rhizomes and leaves of $A$. purpurata

$\begin{array}{lcc}\text { A. purpurata } & \text { DPPH EC50 }(\mathrm{mg} / \mathrm{mL})^{*} & \text { FRAP nmols eq. Trolox/mg extract } \\ \text { Rhizomes } & 0.062 \pm 0.05 & 45.40 \pm 0.64 \mathrm{a} \\ \text { Leaves } & 0.063 \pm 0.16 & 38.60 \pm 0.42 \mathrm{~b}\end{array}$

The results of DPPH are expressed as EC50 (lowest concentration of extract expressing 50\% antioxidant activity). FRAP results are expressed as Trolox equivalents/mg extract in iron reduction. Data expressed as mean \pm SEM $(n=4)$. * not significant according to Student's t-test for independent samples at the $5 \%$ significance level. Means followed by different letters in the column differ according to Student's t-test for independent samples at the $5 \%$ significance level.

The MIC of leaf extracts of $A$. purpurata varied from $18,400 \mu \mathrm{g} \mathrm{mL}^{-1}$ to $32,000 \mu \mathrm{g} \mathrm{mL}^{-1}$ and the MIC of rhizome extracts varied from 9,000 to $21,333 \mu \mathrm{g} \mathrm{mL}^{-1}$ against the isolated bacteria (Table 3). Only for Hafnia alvei was the MIC of rhizome extract significantly lower $\left(9,000 \mu \mathrm{g} \mathrm{mL}^{-1}\right)$ than that of leaf extract $(32,000$ $\mu \mathrm{g} \mathrm{mL}^{-1}$ ) (Table 3).

\section{Table 3}

Mean minimum inhibitory concentrations (MICs) $\left(\mu \mathrm{g} \mathrm{mL}^{-1}\right)$ of aqueous extracts of $A$. purpurata leaves and rhizomes against bacteria isolated from dog nasal swabs

\begin{tabular}{lcc} 
Isolated bacteria & $\begin{array}{c}\text { Leaves } \\
\mu \mathrm{g} / \mathrm{mL}\end{array}$ & $\begin{array}{c}\text { Rhizomes } \\
\mu \mathrm{g} / \mathrm{mL}\end{array}$ \\
\hline Enterobacter agglomerans & 18,400 & 21,333 \\
Escherichia coli & 21,120 & 10,666 \\
Hafnia alvei & $32,000^{\mathrm{a}}$ & $9000^{\mathrm{b}}$ \\
Serratia liquefaciens & 21,333 & 9600
\end{tabular}

Means followed by different letters in the row differ according to Student's t-test $(P<0.05)$.

A. purpurata has been investigated for its medicinal potential, and it has been found that various parts of the plant (rhizomes, leaves, flowers and roots) produce bioactive compounds with therapeutic efficacy. The bioactive compounds produced can act as antimicrobial agents and antioxidants (Soares et al., 2018), and show anticancer, antiinflammatory and neuroprotective effects (Ghosh \& Rangan, 2013), demonstrating the importance of their evaluation against microorganisms isolated from dogs.

The difference in MIC between $A$. purpurata rhizome extract $\left(9000 \mu \mathrm{g} \mathrm{mL} \mathrm{m}^{-1}\right)$ and leaf extract $\left(32,000\right.$ in $\left.\mu \mathrm{g} \mathrm{mL}^{-1}\right)$ (Table 3) against Hafnia alvei suggests a mechanism of antimicrobial action (interaction with the bacteria cell wall) (Romaniuk \& Cegelski, 2015; Soares et al., 2018). Although the content of total phenolic compounds was higher in leaf 
extract, MIC was significantly lower in the rhizome extract. The bioactive compounds present are biochemically diverse (Shareef et al., 2016), so it is possible that in this study, antibacterial activity was related to other bioactive compounds not only phenolic compounds.

For $A$. purpurata rhizome, it was not possible to determine MIC for some bacteria, since the result was above the highest concentration assessed, i.e., above 64,000 $\mu \mathrm{g} \mathrm{mL} \mathrm{m}^{-1}$. These bacteria included a strain of Enterobacter agglomerans, two strains of $E$. coli and a strain of Serratia liquefaciens. This variation in the MIC may be related to the difference in the isolated bacterial strain itself, even whether they belong to the same species.

The results of the present work corroborated Kona et al. (2015). These authors evaluated the antibacterial activity of the ethanolic extracts of leaves, rhizomes and roots of $A$. purpurata by the disc diffusion method against $E$. coli. The results showed that leaf and root extracts were more effective at inhibiting bacterial growth, showing that, most likely, the solvent used in the extraction (ethanol) enabled a high content of phenolic compounds (Kona et al., 2015), which in turn, enabled this greater inhibition.

However, the methanolic extracts from the leaves of several Alpinia species showed no antibacterial activity (disc diffusion method) against E. coli and Staphylococcus aureus in the study conducted by Wong, Lim and Omar (2009). In that study, there was a high content of total phenolic compounds (1189 mg GAE 100g 1) and consequent antioxidant activity, where DPPH was EC50: 0.3-0.4 $\mathrm{mg} \mathrm{mL}^{-1}$ (values above those found in this study -Table 2), but without inhibition of E. coli growth. These results might have been due to the distinct characteristics of the cell wall of gram-negative bacteria, which hinder the interaction of bioactive compounds (phenolic compounds) in inhibiting bacterial growth (Wong et al., 2009) and the method of evaluation (disc-diffusion) that was used in that study.

With regard to $\mathrm{MBC}$, there was great variation among the isolated strains. However, for the rhizome, most strains had MBC above $38,400 \mu \mathrm{g} \mathrm{mL}^{-1}$, which differed from the leaves, in which most strains had MBC above 64,000 $\mu \mathrm{g} \mathrm{mL}^{-1}$, although the content of total phenolic compounds was higher in the aqueous extracts of $A$. purpurata leaves than rhizomes. According to Shareef et al. (2016), the bioactive compounds present in Gingiber officinale Roscoe are biochemically diverse, which could explain the variations in bactericidal activity.

According to Chan and Wong (2015), $A$. purpurata was not sufficiently studied, where there are just two compounds identified in the rhizome, five in leaves and none in flowers. To establish and understand the efficacy of antimicrobial agents (bioactive compounds) of A. purpurata, studies to identify and quantify bioactive compounds are necessary to agree with the understanding of the mechanisms of biological actions. However, Al-Enazi (2018) found that the extract of $A$. purpurata showed a low degree of acute toxicity $\left(L_{50}\right)$ in rats and that it could be used in the treatment of microbial infections.

The results of this work demonstrate the importance of evaluating the antibacterial activity of plants, such as the aqueous extracts of rhizomes and leaves of $A$. purpurata against gram-negative bacteria isolated from dogs 
that showed resistance to antibiotics of the $\beta$-lactam class, which according to Negi (2012), may become a good alternative to conventional antibiotics due to the ability of the bioactive compounds studied here, which are deemed safe by the FDA, to inhibit the growth of pathogenic microorganisms (Azizi et al., 2015).

\section{Conclusion}

The isolated bacteria had a high antibiotic resistance profile against compounds belonging to the penicillin class; however, it should be realized that among the four bacterial species found, three showed intrinsic resistance. The results of this study indicate a potential antibacterial effect of aqueous extracts of rhizomes and leaves of A. purpurata (Vieill). K. Schum (Zingiberaceae). This potential is related to high levels of bioactive compounds (total phenolic compounds), and these extracts could be used together with conventional antibiotics, which could decrease the need for repeat therapy and also contribute to reducing the emergence of bacterial resistance to antibiotics.

\section{Acknowledgment}

This work was carried out with the support of the Executive Board of Research and Post-Graduate Management - DEGPP UNIPAR, and the Coordination for the Improvement of Higher Level Personnel (CAPES) and Brazilian National Council for Scientific and Technological Development (CNPq). Dr. A. Leyva (USA) provided English editing of the manuscript.

\section{Compliance with ethical standards}

This project was approved by the Research Ethics Committee Involving Animal Experimentation (CEPEEA) of Paranaense University under protocol 32876/2018. Nineteen samples of nasal swab were collected from dogs from students of the Veterinary Medicine course of the Paranaense University, UNIPAR, after their authorization.

\section{Conflicts of interest}

The authors declare no conflicts of interest.

\section{References}

Al-Enazi, N. M. (2018). Phytochemical screening and biological activities of some species of Alpinia and Convolvulus plants. International Journal of Pharmacology, 14(3), 301-309. doi: 10.3923/ijp.201.8301. 309

Argudín, M. A., Deplano, A., Meghraoui, A., Dodémont, M., Heinrichs, A., Denis, O., \& Roisin, S. (2017). Bacteria from animals as a pool of antimicrobial resistance genes. Antibiotics, 6(2), 1-12. doi: 10.3390/ antibiotics602001210.3390/ antibiotics6020012

Ayres, M., Ayres, M., Jr., Ayres, D. L., \& Santos, A. S. (2007). BioEstat: aplicações estatísticas nas áreas das ciências biomédicas. Belém: Universidade Federal do Pará.

Azizi, A., Aghayan, S., Zaker, S., Shakeri, M., Entezari, N., \& Lawaf, S. (2015). In vitro effect of Zingiber officinale extract on growth of Streptococcus mutans and Streptococcus sanguinis. International Journal of Dentistry, 2015, 1-5. doi: $10.1155 / 2015 / 489842$ 
Bahr Arias, M. V., \& Carrilho, C. M. D. M. (2012). Resistência antimicrobiana nos animais e no ser humano. Há motivo para preocupação? Semina: Ciências Agrárias, 33(2), 775-790. doi: 10.5433/1679-0359. 2012v33n2p775

Barbosa, L. N., Alves, F. C. B., Andrade, B. F. M. T., Albano, M., Castilho, I. G., Rall, V. L. M., Fernandes, A., Jr. (2014). Effects of Ocimun basilicum Linn essential oil and sodium hexametaphosphate on the shelf life of fresh chicken sausage. Journal of Food Protection, 77(6), 981-986. doi: 10.4315/0362-028X.JFP-13-498

Bona, E. A. M., Pinto, F. G. S., Fruet, T. K., Jorge, T. C. M., \& Moura, A. C. (2014). Comparação de métodos para a avaliação da atividade antimicrobiana e determinação da concentração inibitória mínima (CIM) de extratos vegetais aquosos e etanólicos. Arquivos do Instituto Biológico de São Paulo, 81(3), 218-225. doi: 10.1590/18081657001192012

Bozdogan, B., Berrezouga, L., Kuo, M. S., Yurek, D. A., Farley, K. A., Stockman, B. J., \& Leclercq, R. (1999). A new resistance gene, linB, conferring resistance to lincosamides by nucleotidylation in Enterococcus faecium HM1025. Antimicrobial Agents and Chemotherapy, 43(4), 925-999. doi: 10. 1128/AAC.43.4.925.

Chan, E. W. C., \& Wong, S. K. (2015). Phytochemistry and pharmacology of ornamental gingers, Hedychium coronarium and Alpinia purpurata: a review. Journal of Integrative Medicine, 13(6), 368-379. doi: 10.1016/S20954964(15)60208-4

Clinical and Laboratory Standards Institute (2013). Metodologia dos testes de sensibilidade a agentes antimicrobianos por diluição para bactérias de crescimento aeróbico: norma aprovada (6a ed., Vol. 23, M7-A6.). São Paulo: ANVISA.

Clinical and Laboratory Standards Institute (2018). Performance standards for antimicrobial susceptibility testing. Wayne, PA: CLSI document M100.

Costa, S. L. P., \& Silva, A. C. S., Jr. (2017). Resistência bacteriana aos antibióticos e saúde pública: uma breve revisão de literatura. Estação Científica UNIFAP, 7(2), 45-57. doi: 10.18468/estcien 2017v7n2. p45-57

Cutrim, E. S. M., Teles, A. M., Mouchrek, A. N., Mouchrek, V. E., F., \& Everton, G. O. (2019). Avaliação da atividade antimicrobiana e antioxidante dos óleos essenciais e extratos hidroalcoólicos de Zingiber officinale (gengibre) e Rosmarinus officinalis (alecrim). Revista Virtual de Química, 11(1),60-81. doi:10.21577/19846835.20190006

Del Fio, F. S., Matos, T. R., F., \& Groppo, F. C. (2000). Resistência bacteriana. Revista Brasileira de Medicina, 57(10), 1129-1140.

Drougka, G. E., Foka, A., Koutinas, C. K., Jelastopulu, E., Giormezis, N., Farmaki, O., \& Spiliopoulou, I. (2016). Interspecies spread of Staphylococcus aureus clones among companion animals and human close contacts in a veterinary teaching hospital. Across-sectional study in Greece. Preventive Veterinary Medicine, 126, 190-198. doi: 10.1016/j. prevetmed.2016.02.004

Dupouy, V., Abdelli, M., Moyano, G., Arpaillange, N., Bibbal, D., Cadiergues, M., \& BousquetMélou, A. (2019). Prevalence of betalactam and quinolone/fluoroquinolone resistance in Enterobacteriaceae from dogs in Franceand Spain-characterization of ESBL/pAmpC isolates, genes, and conjugative plasmids. Frontiers in 
Veterinary Science, 6(279), 1-10. doi: 10.3389/fvets.2019.00279

Ghosh, S., \& Rangan, L. (2013). Alpinia: the gold mine of future therapeutics. 3 Biotech, 3(3), 173-183. doi: 10.1007/s13205-0120089-x

Kadwalia, A., Bhoomika, A. K., Thakur, P., Vivekanandhan, R., Jaiswal, S., Patel, K. P., \& Bhawana, R. (2019). Antimicrobial resistant: a glance on emergence spread and combat. Journal of Pharmacognosy and Phytochemistry, 8(2), 995-998.

Kona, L. A., Thofeeq, M. D., \& Venkata, R. (2015). In vitro studies and antibacterial activity of Alpinia purpurata. Austin Journal of Biotechnology \& Bioengineering, 2(4), 1-2.

Kuete, V. (2010). Potential of Cameroonian plants and derived products against microbial infections: a review. Planta Medica, 76(14), 1479-1491. doi: 10.1055/ s-0030-1250027

Leite-Martins, L. R., Mahú, M. I. M., Costa, A. L., Mendes, A., Lopes, E., Mendonça, D. M. V., \& Costa, P. M. (2014). Prevalence of antimicrobial resistance in enteric Escherichia coli from domestic pets and assessment of associated risk markers using a generalized linear mixed model. Preventive Veterinary Medicine, 117(1), 2839. doi: 10.1016/j.prevetmed.2014.09.008

Leite-Martins, L. R., Meireles, D., Beça, N., Bessa, L. J., Matos, A. J. F., \& Costa, P. M. (2015). Spread of multidrug-resistant Escherichia coli within domestic aggregates (humans, pets, and household environment). Journal of Veterinary Behavior, 10(6), 549555. doi: 10.1016/j.jveb.2015.07.040

Lim, C. S. H., \& Lim, S. L. (2013). Ferric reducing capacity versus ferric reducing antioxidant power for measuring total antioxidant capacity. Laboratory Medicine, 44(1), 5155. doi: 10.1309/LM93W7KTF NPZIXRR
Lima, A. P. C. S., Gallani, N. R., Toledo, M. I., \& Lopes, L. C. (2008). Utilização de um sistema de gerenciamento de benefícios farmacêuticos (PBM) para a caracterização do perfil de prescrição e aquisição de antibióticos. Revista Brasileira de Ciências Farmacêuticas, 44(2), 215-223. doi: 10.1590/ S1516-93322008000200007

Macedo, A. M., Jr. (2019). Multirresistência bacteriana e a consequência do uso irracional dos antibióticos. Scire Salutis, 9(2), 1-8. doi: 10.6008/CBPC22369600.2019.002.0001

Manandhar, S., Luitel, S., \& Dahal, R. K. (2019). In vitro antimicrobial activity of some medicinalplantsagainsthumanpathogenic bacteria. Journal of Tropical Medicine, 2019, 1-6. doi: 10.1155/2019/18953 40

Negi, P. S. (2012). Plant extracts for the control of bacterial growth: efficacy, stability and safety issues for food application. International Journal of Food Microbiology, 156(1), 7-17. doi: 10.1016/j. ijfoodmicro. 2012.03.006

Otunola, G. A., Oloyede, O. B., Oladiji, A. T., \& Afolayan, A. J. (2014). Selected spices and their combination modulate hypercholesterolemia-induced oxidative stress in experimental rats. Biological Research, 47(1), 1-6. doi: 10.1186/07176287-47-5

Paula, C. G. D. (2014). Análise de prescrições de medicamentos antimicrobianos dispensados em uma farmácia comunitária no município de João Pessoa, Paraíba. Revista Especialize on-line IPOG, 1(9), 1-14.

Pyrzynska, K., \& Pekal, A. (2013). Application of free radical diphenylpicrylhydrazyl (DPPH) to estimate the antioxidant capacity of food samples. Analytical Methods, 5(17), 6-11. doi: 10.1039/C3AY40367J 
Quinn, P. J., Carter, M. E., Markey, B., \& Carter, G. R. (1994). Clinical veterinary microbiology. St. Louis: Mosby.

Romaniuk, J. A. H., \& Cegelski, L. (2015). Bacteria cell wall composition and the of antibiotics by cell-wall and whole-cell NMR. Philosophical Transactions of the Royal Society B, 370(1), 1-14. doi: 10.1098/ rstb.2015.0024

Sahoo, S., Singhi, S., \& Nayak, S. (2014). Chemical composition, antioxidant and antimicrobial activity of essential oil and extract of Alpinia malaccensis Roscoe (Zingiberaceae). International Journal of Pharmacy and Pharmaceutical Sciences, 6(7), 183-188.

Shareef, H. K., Muhammed, H. J., Hussein, H. M., \& Hameed, I. H. (2016). Antibacterial effect of Gingiber officinale Roscoe and bioactive chemical analysis using gas chromatography mass spectrum. Oriental Journal of Chemistry, 32(2), 817-837. doi: 10.13005/ojc/320207

Singleton, V. L., \& Rossi, J. A. (1965). Colorimetry of total phenolics with phosphomolybdicphosphotungstic acid reagents. American Journal of Enology and Viticulture, 16, 144-158.

Soares, A. A., Jacomassi, E., Mata, R., Lopes, K. F. C., Borges, J. L., Pereira, U. P., \& Gonçalves, D. D. (2018). Antimicrobial activity of species Zingiber officinale Roscoe and Alpinia purpurata (Vieill.) K. Schum (Zingiberaceae) - review. Semina: Ciências Agrárias, 39(4), 1849-1862. doi: 10.5433/1679-0359.2018v39n4p1849

Sumabranian,V.,\&Suja,S.(2011).Phytochemical screening of Alpinia purpurata (Vieill). Research Journal of Pharmaceutical, Biological and Chemical Sciences, 2(3), 866-871. doi: 10.5433/1679-0359.2018v 39n4p1849
Urumova, V. S. (2019). Prevalence of resistance to some beta-lactams among commensal canine E. coli isolates. Bulgarian Journal of Veterinary Medicine, 22(3), 330-336. doi: 10.15547/bjvm.2255

Villaflores, O. B., Macabeo, A. P. G., Gehle, D., Krohn, K., Franzblau, S. G., \& Aguinaldo, A. M. (2011). Phytoconstituints from Alpinia purpurata and their in vitro inhibitory activity against Mycobacterium tuberculosis. Pharmacognosy Magazine, $6(24)$, 339-344. doi: 10.4103/09731296.71785

Wendlandt, S., Shen, J., Kadlec, K., Wang, Y., Li, B., Zhang, W.,... Schwarz, S. (2015). Multidrug resistance genes in staphylococci from animals that confer resistance to critically and highly important antimicrobial agents in human medicine. Trends in Microbiology, 23(1), 1-11. doi: 10.1016/j. tim.2014. 10.002

Wieler, L. H., Ewers, C., Guenther, S., Walther, B., \& Lubke-Becker, A. (2011). Estafilococos resistentes à meticilina (MRS) e Enterobacteriaceae produtoras de betalactamases de espectro estendido (ESBL) em animais de companhia: infecções nosocomiais como uma razão para o aumento da prevalência desses patógenos zoonóticos potenciais em amostras clínicas. International Journal of Medical Microbiology, 301(8), 635-641. doi: 10.1016/j.ijmm.2011.09.009

Wong, L. F., Lim, Y. Y., \& Omar, M. (2009). Antioxidant and antimicrobial activities of some Alpinia species. Journal of Food Biochemistry, 33(6), 835-851. doi: 10.1111/j.1745-4514.2009.00258.x 